\title{
Author Correction: Structural determinants and functional consequences of protein affinity for membrane rafts
}

Joseph H. Lorent ${ }^{1}$, Blanca Diaz-Rohrer ${ }^{1}$, Xubo Lin (10 ${ }^{1}$, Kevin Spring ${ }^{1}$, Alemayehu A. Gorfe ${ }^{1}$, Kandice R. Levental ${ }^{1}$ \& Ilya Levental (iD ${ }^{1}$

Correction to: Nature Communications https://doi.org/10.1038/s41467-017-01328-3; published online 31 October 2017

In the originally published version of this Article, financial support was not fully acknowledged. The PDF and HTML versions of the Article have now been corrected to include support from National Institute of General Medical Sciences, National Institutes of Health grant R01GM124072.

Published online: 01 May 2018

(c) (i) Open Access This article is licensed under a Creative Commons Attribution 4.0 International License, which permits use, sharing, adaptation, distribution and reproduction in any medium or format, as long as you give appropriate credit to the original author(s) and the source, provide a link to the Creative Commons license, and indicate if changes were made. The images or other third party material in this article are included in the article's Creative Commons license, unless indicated otherwise in a credit line to the material. If material is not included in the article's Creative Commons license and your intended use is not permitted by statutory regulation or exceeds the permitted use, you will need to obtain permission directly from the copyright holder. To view a copy of this license, visit http://creativecommons.org/licenses/by/4.0/.

(c) The Author(s) 2018

\footnotetext{
${ }^{1}$ McGovern Medical School, University of Texas Health Science Center, Houston MSB 4.202A, 6431 Fannin St, 77096 Houston, TX, USA. Correspondence and requests for materials should be addressed to I.L. (email: ilya.levental@uth.tmc.edu)
} 